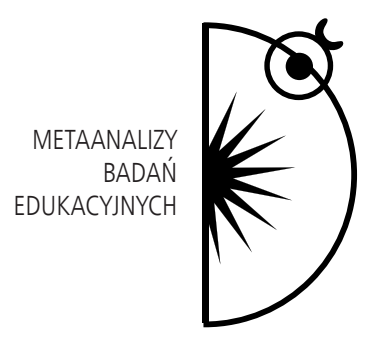

Aleksander Nalaskowski

\title{
Autowanie pedagogiki
}

DOI: http://dx.doi.org/10.12775/PBE.2013.001

Przygotowując ten tekst, sięgnąłem do podobnych tematycznie opracowań sprzed 10, 15 i 20 lat. Moje wrażenie było następujące: chyba mówimy wciąż o tym samym. Jak mantrę, z generacji na generację, powielamy zupełnie niezrozumiałe kompleksy. Pedagogika wydaje się być dyscypliną, która pod względem samokrytycyzmu, obecnego głównie na konferencjach, i wręcz masochistycznego znęcania się nad sobą nie ma sobie równych. Tutaj osiągnęliśmy mistrzostwo świata. Tymczasem, jest to moja teza wyjściowa, nikt tak dobrze jak my nie rozumie współczesności i zachodzących w niej procesów. Nikt tak dobrze jak my nie rozumie, że w życiu na nic nie ma prostych recept. Ale też chyba nikt inny nie jest tak bierny, posiadając jednocześnie takie kompetencje.

Wyjaśnijmy co oznacza my. Otóż jest to dość spora grupa profesorów, doktorów, a niekiedy nawet studentów, która jak każda frakcja jest otoczona niemałym wianuszkiem hochsztaplerów, miernot, świetnie wyhabilitowanych nieporozumień. Ale tak jest wszędzie. Rotmistrz W. Pilecki był bohaterem dlatego, że inni panicznie się bali wojny. Każdy pociąg ma potężną lokomotywę i sromotnie ostatni wagon. Niedawno w czasie jednej z komisji uczelnianych któryś z dziekanów pastwił się nad wydrukiem tekstu habilitacji z pedagogiki, w którym autorka napisała „Macierzyństwo różni się od ojcostwa”. Śmiechom nie było końca. Ale następne zdanie brzmiało: „Różni się nie tylko w wymiarze naturalnym, ale także w sensie prawnym. Widać to m.in. w postępowaniach rozwodowych i procedurach pozbawiania praw rodzicielskich. To dwie różne filozofie prawa”. Oczywiście już tego zdania dumny „ścisłowiec” nie przywo- 
łał. Byłoby mniej zabawnie. Poniżej trzy przykłady niebotyczności poziomu z innych obszarów nauki.

Pierwszy przykład. Jedna z najbliższych mi osób pisała pracę na temat melioracji gruntów w pewnej gminie. Korzystała przy tym z drogich zdjęć lotniczych, wykonała setki próbek gruntu i oczywiście dotarła do literatury. Wśród książek opisujących skutki melioracji pól uprawnych na konkretnym obszarze, konkretnej (mającej nazwę i współrzędne) wsi znalazł rozprawę odnoszącą się do roślinności (jej typu, żywotności, charakteru) przed zabiegami odwadniającymi i po nich. Książka ta opisywała szczegółowo sposób układania nitek wodnych, osadzania zlewni, nadrozrodczości wierzb, kwaśności traw i innych skutków tego zabiegu agrotechnicznego. Po trzech latach autor powrócił na ten teren i wskazując zlewnię, przebieg kanałów wodnych i rowów melioracyjnych, ukazał diametralne zmiany zarówno w zakresie występowania roślinności, jak i mineralnej analizy gleby. Podążając jego śladem, młody badacz dowiedział się, że w 1983 r. zablokowano program melioracji i na terenie wskazywanym w książce nigdy melioracji nie przeprowadzono. Co więcej, autor przywołanej pozycji był konsultantem procesu melioracyjnego i jako ekspert podpisywał się pod dokumentami stwierdzającymi prawidłowość technicznego przeprowadzania budowy urządzeń melioracyjnych, których nigdy nie było. Był wpisany w szeroki program tzw. problemów węzłowych. Jego książka oraz rzekome badania były finansowane przez państwo, na tej podstawie uzyskał habilitację.

Drugi przykład. Z powodu swoich zainteresowań przeglądnąłem opublikowaną rozprawę doktorską z zakresu nauk przyrodniczych. Głowna teza pracy, będąca jej końcowym wnioskiem, głosi: lepiej kryć klacze dobrym materiałem genetycznym, gdyż w ten sposób podwyższa się prawdopodobieństwo uzyskania wartościowego przychówku. Czy ktoś z Państwa o tym nie wiedział?

Trzeci przykład. Poproszony kiedyś o przetłumaczenie tekstu z zakresu urologii, dowiedziałem się, że przerost gruczołu prostaty u mężczyzn występuje pomiędzy pięćdziesiątym a dziewięćdziesiątym rokiem życia. Mój brat, który nie ma nic wspólnego z nauką, lecz jest od 35 lat praktykującym chirurgiem urologiem skwitował to następująco: „najmłodszy pacjent, którego operowałem z tego powodu, miał 49 lat, a najstarszy 88 ". To proste spostrzeżenie - praktyka warta jest 20 punktów parametrycznych w wycenie naukowej. To, co dla pospolitego praktyka, jest oczywistością, dla ambitnego badacza stało się przepustką do elitarnej kasty publikującej w drogim, międzynarodowym magazynie specjalistycznym.

We wszystkich dyscyplinach naukowych, także i tych najbardziej prestiżowych jest miejsce na złą metodologię, nieuczciwość i banał. A. Awdiejew 
stwierdził kiedyś, że Francuzi czy Niemcy spożywają tyle samo alkoholu, co Rosjanie, ale ci ostatni potrafią to piękniej pokazać. Podobnie jest chyba z nami. Użalamy się nad poziomem naszej nauki, chwilami zapominając, że każda masa ludzi, jakakolwiek by nie była, wygeneruje swoje elity, średniaków i „ogony”. Na uniwersytecie w Zurichu na początku tego wieku na wydziale fizyki (raczej na jego odpowiedniku) było zatrudnionych ponad dwudziestu wykładowców. Znamy tylko jednego, który przeszedł do kanonu popkultury przy pomocy ślicznego $E=\mathrm{mc}^{2}$.

W chwili gdy odbywamy nasze spotkanie, cała Polska, a pewnie i Europa, emocjonuje się poczynaniami futbolistów. Stąd moje nawiązanie do pojęcia autu, czyli piłki, która wypada poza końcową linię boiska. Piłki, która w tym momencie nie liczy się w grze, która na tę chwilę staje się nieważna, a rzec by można - nieistotna. Jesteśmy autowani na trzy sposoby.

\section{Autowanie strukturalne}

Niejako wbrew naszej woli i przy pomocy instrukcji administracyjnej, na którą nigdy nie wydaliśmy zgody, zostaliśmy wydaleni, a właściwie wyrzuceni poza obręb nauk humanistycznych do bliżej nieokreślonych nauk społecznych. Moim zdaniem jest to przesunięcie pedagogiki ze sfery pożytku publicznego do sfery złotoustych karierowiczów.

My, refleksyjni i zatroskani, zostaliśmy zaliczeni w poczet komentujących doraźność „ujadaczy” medialnych publikujących także w „CKM” czy „Playboyu". W ten sposób znaleźliśmy się poza humanistyką, czyli jedyną dziedziną wiedzy, która dała nam wszystkich bez wyjątku noblistów. Przed uniwersyteckimi wydziałami przyrodniczymi czy ścisłymi, a także ekonomicznymi miejsca parkingowe dla noblistów stoją wciąż puste. Jakby na przekór, im bardziej są puste, tym większa panuje pogarda dla humanistów. Doprawdy, nie było żadnego powodu, aby pedagogika znalazła się poza humanistyką. Jest to przykład płaskiego, kompletnie nieukorzenionego sposobu myślenia i działania w obszarze nauki. Mam nadzieję, że przyjdzie czas, iż skutecznie się o to upomnimy.

\section{Autowanie parametryczne}

Wprowadzenie oceny parametrycznej, która ma kilka wymiarów, stało się budowlą, a właściwie złotym cielcem postawionym na cokole nieporozumienia. Pierwszym elementem tego nieporozumienia jest niedopracowane, punktowe szacowanie wartości publikacji. Książka, która ukazała się w dobrym, ogól- 
nopolskim wydawnictwie i uzyskała sprzedaż ponad sześciu tys. egzemplarzy w dwóch wydaniach, jest w optyce parametrycznej mniej wartościowa niż artykuł opublikowany w jednym z kilku punktowanych czasopism niedorównujących nakładem owej książce ${ }^{1}$.

Ktokolwiek zna specyfikę nauk humanistycznych, wie, jak powstają naukowe rozprawy i czym się różnią od artykułów będących często konferencyjnymi referatami. Nadto każdy humanista ma własny profil, własny naukowy modus operandi. Wydałem kilkanaście książek, a oprócz tego kilka z nich ukazało się za granicą, lecz niechętnie pisuję artykuły. Głównie dlatego, że mój naukowy cykl przebiega od książki do książki bez przystanków po drodze. Proszę mi wybaczyć ten autobiograficzny wtręt, ale jest to najbliższy mi przykład. Jeszcze w tym artykule dwukrotnie się doń odwołam.

Niezwykle popularnym wskaźnikiem oceny ważności tekstów jest tzw. impact factor, czyli - najogólniej rzecz ujmując - współczynnik wpływu danego tekstu na kształt danej dyscypliny naukowej. W naukach ścisłych i przyrodniczych, pozbawionych lokalnego kontekstu, jest on być może trafny. Nie wiem, nie zajmuje mnie to. Natomiast w naukach humanistycznych wydaje się być nieporozumieniem. Jest próbą zmiany tradycji i źródeł naszej wiedzy, opartej na głębokim namyśle i refleksji, w doraźną karierę wytworu. I nie byłoby to takie ważne, bo ostatecznie można to zignorować i robić swoje. Jestem, jak wielu obecnych tu kolegów, w sytuacji, w której nie muszę nikogo przekonywać co do swojej obecności w naszej dziedzinie. Jednakże taki egoizm byłby ze szkodą dla mojego środowiska, bo kiedyś wyżyny biurokracji żądają szczegółowych sprawozdań i raportów, na podstawie których drużynowo przyznaje się fundusze, a zatem realny warunek przetrwania danej jednostki.

Do czego prowadzi sumowanie punktów, ustalanie wzorów obliczeń i kategoryzacji osiągnięć, pokazują rankingi uczelni wyższych będące obrazem zupełnie nieistniejącego w realnym życiu akademickim wizerunku. Co więcej, punktowa parametryzacja bywa demoralizująca. Zmusza bowiem do wysuwania na plan pierwszy zabiegów o atrakcyjność dla wydawcy, której nie należy mylić z atrakcyjnością dla nauki i odbiorców. Powstają spółdzielnie stosujące zasadę „ty cytujesz mnie, ja cytuję ciebie”. Niedawno otrzymałem list e-mailowy, w którym nieznany mi doktor socjologii napisał: „Witam, w załączniku

Zob. J. Strelau, Tekst Stanowiska Wydziatu I Nauk Humanistycznych i Społecznych PAN $w$ sprawie parametryzacji osiagnięć naukowych przedstawicieli nauk humanistycznych i społecznych; http://sliwerski-pedagog.blogspot.com/2013/07/wyborcza-reprodukcja-w-humanistyce-i. html (dostęp: 07.2013); http://www.wnhip.uni.wroc.pl/uploads/list_parametryzacja_okon.pdf (dostęp: 07.2013). 
zamieszczam wykaz pięciu artykułów wraz z krótkim streszczeniem każdego z nich. Byłbym wdzięczny za zacytowanie w pana publikacjach". Z informacji wynikało, że byłem jednym z wielu adresatów. Czy tak ma wyglądać nauka? Czy tak ma wyglądać ocena naszej pracy? W wykazach bibliotecznych, w nowomowie określanych jako bibliometria, wpływ na pedagogikę K. Sośnickiego, B. Suchodolskiego, S. Kunowskiego, S. Hessena, a także Z. Kwiecińskiego jest... zerowy. Znalazłem się w tym elitarnym gronie. Osobnym zagadnieniem jest to, kto kogo cytuje i z jakiego powodu. Swego czasu ukazała się książka habilitacyjna z zakresu historii wychowania, w której autorka napisała kilka ewidentnych bredni o międzywojennych uniwersytetach polskich. Książka stała się obiektem miażdżącej krytyki zamieszczonej w tekstach publikowanych w renomowanych wówczas (było to przed parametryzacją) czasopismach fachowych. A zatem była licznie cytowana i dzisiaj miałaby pewnie imponujący impact factor. Jeden z naszych kolegów prowadzi blog pedagogiczny. Ma dziennie po kilkaset wejść. Oczywiście według narzuconych nam kluczy nie wywiera wpływu na naukę. Pomijając wypromowanych przeze mnie 15 doktorów, sporządzenie niemal setki recenzji habilitacyjnych, doktorskich i profesorskich, a nawet do tytułu doktora hc, nie umiem sobie pozwolić na myślenie, że założona przeze mnie i prowadzona do dziś szkoła z blisko ćwierćwiekowym stażem nie wywarła wpływu na pedagogikę. Daliśmy się zagonić w pułapkę zastawioną przez technokratów. To bardzo wygodna metoda marginalizacji humanistyki, która nie karmi, nie buduje mostów i nie służy (jak większość nauk ścisłych i przyrodniczych) ,zbrojeniówce”. Z pewnym zdziwieniem patrzę, jak część naszych kolegów chętnie przystała na tak rozumianą parametryzację, jak posłusznie stworzyła wizerunek pedagogiki jako nauki przyrodniczej, która będzie się teraz zmagać z garbem własnej odmienności.

\section{Autowanie praktyczne}

Wielokrotnie podkreślamy, że pedagogika jest nauką praktyczną. Taka opinia ma swoje korzenie jeszcze w pedagogice międzywojennej. Także teraz trudno byłoby ją sfalsyfikować inaczej. Tym bardziej musi dziwić nasza nieobecność w praktyce. Owo przenikanie profesury do wychowawczej rzeczywistości jest nadzwyczaj oporne. Jak mi się wydaje, wynika to z dwóch faktów.

Pierwszy z nich to najczęstsza ścieżka stawania się uczonym, czyli studia studia doktoranckie - etat na uczelni. W takim wypadku jedyną praktyką, jedynym doświadczeniem realnym jest nauczanie studentów, co w żaden sposób nie jest ekwiwalentne dla obecności w szkole, w domu dziecka czy poradni. Tylko 
bowiem ciągły kontakt z naszym „pacjentem” daje możliwość weryfikowania tego, o czym piszemy.

Od lat w wystąpieniach i książkach piszę o głębokich różnicach pomiędzy rzeczywistością szkolną (zajmuję się wszak szkołą) a jej wizerunkiem w opisie naukowym. Można by nawet powiedzieć, że spory segment prac pedagogicznych to rodzaj świata wirtualnego. Posunąłem się kiedyś do określenia, że pedagogika akademicka staje się coraz bardziej odmianą gatunku literackiego. Brak doświadczeń i „dotkniętej” wiedzy w zakresie realiów polskiego wychowania i kształcenia powoduje rozbudowę nisz pedagogicznych, pozostających jednakże poza głównym nurtem naszej nauki. Wyraźna socjologizacja pewnej części naszego środowiska daje usprawiedliwienie dla zaledwie orzekania o tym, jak jest, ze zgodnym milczeniem na temat, jak być powinno, a nade wszystko, jak owo „powinno” wprowadzić w życie.

Dwadzieścia pięć lat zanurzenia w edukacyjnej codzienności przybierającej kształt tworzenia, prowadzenia, rozwijania szkoły, uczestnictwa w zebraniach i konferencjach kuratoryjnych, ustawicznego kontaktu z młodzieżą w wieku gimnazjalnym, licealnym, studenckim, doktorskim i podoktorskim, a także dziesiątki autorskich wystąpień na pozaakademickich spotkaniach z nauczycielami daje mi prawo, a przynajmniej pewne podstawy do spostrzeżenia, że nasze akademickie dokonania rozmijają się z rzeczywistością szkolną i jej koniecznościami. Wiele prac roi się od imperatywów „trzeba”, „powinno się”, „należy”, „musi” bez wskazania, ,jak”. Oczywiście znam argumenty obalające moją opinię. Wiem, że uniwersytet to nie szkoła zawodowa, że nic bardziej praktycznego jak dobra teoria, że chcemy dobrze, ale nas nie słuchają. Wprost nie mogę więc wyjść ze zdumienia, jak MEN mógł przeoczyć - tak ważne dla obecnej szkoły w rozwiązywaniu jej terminalnych problemów - publikacje o tożsamości płciowej nauczycieli czy wartości biwaków zwanych teraz „zielonymi szkołami”.

Gdy dotknie nas choroba, poszukujemy kontaktu z profesorami medycyny. W ciągu ostatnich trzech lat doświadczyłem czterech takich spotkań i każde z nich poprawiło mój stan. Każdy z profesorów bowiem umiał coś naprawdę. Żaden na mój widok nie snuł przypowieści o filozofii zdrowia, nie pouczał o przemijalności życia, lecz brał do ręki skalpel i czynił cuda.

Drugim powodem naszej nieobecności w praktyce jest wyautowanie pożytecznej ingerencji w rzeczywistość poza sferę dorobku naukowego, a właściwie poza sferę istotności. Kto dziś interesuje się autorskimi dokonaniami profesora B. Śliwerskiego? Kto wie o zupełnie niecodziennej metodzie profesora F. Wojciechowskiego? Kto pamięta o szkołach na Łotwie tworzonych przez profesor 
M. M. Urlińską? Prawie nikt, a w każdym razie niewielu. Bywa, że zabieram głos w sprawach publicznych. Obszerne teksty ukazują się zarówno w dziennikach, tygodnikach, jak i miesięcznikach popularnych, jakkolwiek skierowanych do określonego odbiorcy. Ukazują się też na portalach internetowych, gdzie w ciągu dnia zyskują tysiące czytelników. Bez względu na moją postawę i poglądy, czyż można uznać, że nie istnieję w życiu społecznym?

Z punktu widzenia parametryzacji i szacunków punktowych są to przykłady działalności bezwartościowej. Wystarczy, że w „naukowym” gremium wspomni się o działalności praktycznej i natychmiast spada się do drugiej ligi uczonych. Tak naprawdę we własnym gronie też tego nie cenimy. Na naszych oczach, na oczach zawodowych pedagogów kolejni ministrowie doprowadzają szkołę do ruiny. Tym razem jednak nadzwyczaj skutecznie. Zwalnianie nauczycieli i likwidacja szkół to eutanazja dokonywana w imię ekonomii. A my się dziś roztkliwiamy nad współczynnikami korelacji statystycznej.

Niedawno dostałem dwie propozycje $\mathrm{z}$ dwóch różnych ministerstw edukacji. Jedna z Węgier, druga z Urugwaju, abym do nich pojechał i stworzył sieć szkół opartą na modelu Szkoły Laboratorium. Nie jest to zasługa mojej „wielkości” akademickiej, lecz wynik jednego wywiadu udzielonego zagranicznemu magazynowi, w którym dziennikarz kompetentnie dopytywał o szczegóły funkcjonowania naszej placówki. No i efekt prowadzenia jej przez bez mała ćwierć wie$\mathrm{ku}$, przez tę samą osobę, z niemal tym samym zespołem. Potem były rozmowy, wizyty w Szkole Laboratorium, a na końcu propozycja. Wyraźnie odczułem, że fakt prowadzenia szkoły czynił mnie atrakcyjniejszym jako profesora. Być może skorzystam z którejś z ofert. Jest co rozważać.

W jednej ze swoich ostatnich prac Z. Kwieciński nazwał mnie mistrzem pedagogicznego eseju. Dodałbym „zaledwie” eseju. Mam więc nadzieję, że i tym razem moje intencje dobrze przedstawiłem i są czytelne.

\section{Marginalization of pedagogy}

\section{Summary}

The article deals with the situation of Polish pedagogy as an academic science. The author shows the processes leading to marginalization, or even disregard of pedagogy in the currant structure of management of science. The article presents legal and customs-related paradoxes due to which pedagogy loses its identity and grows in the shadow of other social studies. 